\title{
Correlation of viable cell counts, metabolic activity of sulphur-oxidizing bacteria and chemical parameters of marine sediments
}

\author{
J. F. Imhoff, A. Schneider \& L. Podgorsek \\ Institut für Meereskunde, Abteilung Marine Mikrobiologie; \\ Düsternbrooker Weg 20, D-24105 Kiel, Germany
}

\begin{abstract}
Viable counts of aerobic and anaerobic chemotrophic sulphur-oxidizers as well as phototrophic sulphur bacteria were determined in sediment samples taken from two different areas along the Baltic Sea shore which were known to regularly develop sulphidic conditions. Depth profiles of bacterial cell counts were correlated with concentration profiles of chloride, sulphate, sulphide, nitrate and phosphate in the pore water of these sediments and with potential activities of nitrate reduction, thiosulphate transformation and sulphate formation. The data revealed a complex multilayered structure within the sediments. Sulphide was released into the water from sediments of both sampling areas, but it was found that light and the availability of oxygen significantly reduced this amount. In the highly reduced sediment at Hiddensee, the highest numbers of phototrophic and chemotrophic sulphur-oxidizers were found near the sediment surface. Therefore, it was concluded that the combined action of both groups of bacteria most efficiently oxidizes reduced sulphur compounds in the top layers of the sediments. Nitrate may replace oxygen as final electron acceptor and will support oxidation of sulphide, in particular when oxygen and light are limiting.
\end{abstract}

\section{INTRODUCTION}

The increasing eutrophication of marine coastal areas, in particular its correlation with increases of sulphidic locations in marine basins and coastal areas, has renewed interest in reactions of the microbial sulphur cycle and its importance for these environments. A considerable part of the organic matter in marine sediments is mineralized by sulphate-reducing bacteria (Jörgensen, 1982). In general, these bacteria have a selective advantage over methanogenic bacteria in the marine environment. The methanogens can compete only when sulphate is limiting, when organic substrates are supplied in excess or when alternative non-competitive substrates, like methylamine, are available (Widdel, 1988). Sulphate reduction leads to the production of sulphide, which is toxic to bacteria, animals and plants. Sulphide is released from sediments into the supernatant water and also into the atmosphere from coastal areas like the Wadden Sea and the shallow areas of the Baltic Sea shore.

Most of the sulphide produced in marine sediments is supposed to be oxidized by bacterial activity rather than chemically. Important intermediates in the oxidation of sulphide are elemental sulphur and thiosulphate (Jörgensen \& Bak, 1991). The latter also is one of the most convenient sources of reduced sulphur for the cultivation of bacteria 
that oxidize reduced sulphur compounds. Although three major physiological groups of bacteria with such activities are known - the aerobic sulphur-oxidizers, the nitratereducing sulphur-oxidizers, and the phototrophic sulphur bacteria - only a small number of species of these bacteria have been identified from the marine environment. Information on their distribution and frequency in marine habitats is rare. The present study was initiated in order to correlate viable numbers of bacteria participating in the bacterial sulphur cycle with chemical parameters from the sediments and to locate bacteria and their activities within the sediment layers.

\section{MATERIAL AND METHODS}

The sampling sites: Two sampling sites that were known to develop regularly sulphidic conditions were selected for our analyses. The first site, close to the Island of Hiddensee, represents an open reed belt with highly reduced sediment, which has already been described by Suckow (1966). The sampling occurred during a time of highly fluctuating water levels (from $0-20 \mathrm{~cm}$ ) above the sediment. The other site is located near Fährdorf, close to Poel, and may be described as a small, nearly closed reed bight. During the sampling period, it appeared oxidized at the surface, but was reduced at deeper levels. At that time the weather was calm and there was a constant water level above the sediment of $1-5 \mathrm{~cm}$. The structure of the sediment near Fährdorf was more homogeneous and consisted of a smaller grain size than that of Hiddensee.

Sampling of sediments: The sampling occurred during June 1992. Sediment cores were directly cut into discs of 1 to $5 \mathrm{~cm}$ thickness, as noted in Tables 1 and 2 . Correlation of the different parameters required an immediate treatment of the discs according to the methods listed below. Therefore, and because of the great number of simultaneous analyses and experiments, statistical treatment of the sediment cores was not possible. However, corresponding disks from 3-5 sediment cores taken from the same location were combined, carefully mixed and used for further treatments.

$\mathrm{Ch}$ emical an alyses: Pore water from the sediment discs was recovered after centrifugation and sterilized by filtration $(0.45 \mu \mathrm{m}$ pore size cellulose acetate membrane filters). This water was used to determine concentrations of chloride, sulphate, nitrate and phosphate. Separation and quantification of these anions was achieved by ion chromatography using a Dionex DX 300, equipped with conductivity- and UV-detectors and an anion exchange column (Dionex-AS4A). Chemical analyses were made at three different sensitivity ranges of the conductivity detector. The salinity was calculated from the concentration of chloride (salinity $=1.80655 \cdot$ chlorinity) according to Wooster et al. (1969).

Samples for determination of sulphide were taken immediately after the pore water was recovered by centrifugation and taken from the clear supernatant close to the sediment. Sulphide was determined as methylene blue, according to the method described by Lorant (1929) and modified by Pachmayr (1960). Sulphide was stabilized as $\mathrm{ZnS}$ in a $20-\mathrm{ml}$ volumetric flask containing $10 \mathrm{ml}$ of $2 \% \mathrm{Zn}$-acetate (acidified with $1 \mathrm{ml}$ $2 \mathrm{M}$ acetic acid per litre) and than stored at $4^{\circ} \mathrm{C}$. Reagents were $0.2 \%$ dimethyl-pphenylendiammoniumdichlorid (DMPD) in $20 \%$ sulphuric acid, which had to be stored in the dark and $10 \% \mathrm{NH}_{4} \mathrm{Fe}\left(\mathrm{SO}_{4}\right)_{2} \times 12 \mathrm{H}_{2} \mathrm{O}$ (FAS) in $0.02 \%$ concentrated sulphuric acid. After addition of $2 \mathrm{ml}$ DMPD and $0.1 \mathrm{ml}$ FAS, the flasks were closed immediatelv and 
allowed to stand for at least $30 \mathrm{~min}$. After colour development was completed, the sample volume was adjusted to a total of $20 \mathrm{ml}$ and the optical density measured at $668 \mathrm{~nm}$ against a reagent blank.

Bacterial analyses: In order to overcome small-scale heterogeneity of the sediments, corresponding sediment discs of 3-5 cores from each sampling sites were homogenously mixed, and volumes of $0.5 \mathrm{~cm}^{3}$ sediment were used for dilution series. The dilution was performed in $70 \%$ filter-sterilized, natural seawater (taken from the North Sea near List/Sylt). From these dilution series, various media were inoculated. The material was either spread on plates (for aerobic bacteria) or inoculated in deep-agar (for anaerobic bacteria).

Phototrophic bacteria were cultivated in Pfennig's medium, supplemented with acetate solution $(1 \mathrm{ml} / 100 \mathrm{ml})$ and salt solution $(5 \mathrm{ml} / 100 \mathrm{ml})$ according to Pfennig \& Trüper (1992). Cell counts were obtained from dilution series in agar.

A new medium ("Lith" medium) was designed for marine anaerobic sulphuroxidizing bacteria, using different electron acceptors. The composition of the basic mixture of the medium contained in final amounts per litre: $700 \mathrm{ml}$ of a modified, sulphate-free sea water (MSM), $1.68 \mathrm{~g} \mathrm{NaHCO}_{3}, 0.68 \mathrm{~g} \mathrm{KH}_{2} \mathrm{PO}_{4}, 0.25 \mathrm{~g} \mathrm{NH}_{4} \mathrm{Cl}, 1 \mathrm{ml}$ trace element solution SLB (modified SLA with only $1 \mathrm{mg} \mathrm{Na} \mathrm{SeO}_{3} \cdot 5 \mathrm{H}_{2} \mathrm{O}$ per litre) and $1 \mathrm{ml}$ vitamin solution VA (Imhoff, 1988). The modified, sulfate-free sea water (MSM) was autoclaved separately and contained the following amounts per litre: $27.3 \mathrm{~g} \mathrm{NaCl}, 2.7 \mathrm{~g}$ $\mathrm{MgCl}_{2} \cdot 6 \mathrm{H}_{2} \mathrm{O}, 0.75 \mathrm{~g} \mathrm{KCl}, 0.4 \mathrm{~g} \mathrm{CaCl}_{2} \cdot 2 \mathrm{H}_{2} \mathrm{O}$, and $0.14 \mathrm{~g} \mathrm{KBr}$. The $\mathrm{pH}$ was adjusted to 7.2. A mixture of $\mathrm{Na}_{2} \mathrm{~S}_{2} \mathrm{O}_{3} \cdot 5 \mathrm{H}_{2} \mathrm{O}, \mathrm{Na}_{2} \mathrm{~S} \cdot 9 \mathrm{H}_{2} \mathrm{O}$ and polysulphide (prepared according to Feher \& Laue, 1956) was applied as a source of reduced sulphur in final concentrations of $5 \mathrm{mM}, 0.5 \mathrm{mM}$ and $13 \mathrm{mM}$, respectively. $\mathrm{NaHCO}_{3}$ and sodium acetate $(5 \mathrm{mM})$ were added as the only carbon sources. Either $\mathrm{KNO}_{3}(10 \mathrm{mM})$ or $\mathrm{Na}_{2} \mathrm{SO}_{4}(10 \mathrm{mM})$ served as electron acceptors.

Aerobic bacteria were counted on agar plates using a mineral salts medium ("Thio" medium). The basic medium contained $700 \mathrm{ml}$ natural sea water, $0.4 \mathrm{~g} \mathrm{NH}_{4} \mathrm{Cl}$ and $0.5 \mathrm{~g}$ $\mathrm{KH}_{2} \mathrm{PO}_{4} . \mathrm{NaHCO}_{3}(1.0 \mathrm{~g} / \mathrm{l})$ and sodium acetate $(5 \mathrm{mM})$ were added as carbon sources, and sodium thiosulphate $(3.2 \mathrm{mM})$ and $\mathrm{Na}_{2} \mathrm{~S} \cdot 9 \mathrm{H}_{2} \mathrm{O}(0.5 \mathrm{mM})$ as sulphur sources and electron donors. The $\mathrm{pH}$ was adjusted to 7.2

Measurements of bacterial activities: Transformation of thiosulfate was measured under aerobic conditions in shaken Erlenmeyer flasks and under anaerobic conditions with $\mathrm{KNO}_{3}(7 \mathrm{mM})$ as added electron acceptor. Anaerobic conditions were achieved in Hungate tubes by repeated evacuation and flushing with nitrogen gas. Assays were performed under nitrogen and in the dark. For all activity measurements, the basal medium for anaerobic bacteria was supplemented with sodium acetate (5 mM) and $\mathrm{Na}_{2} \mathrm{~S}_{2} \mathrm{O}_{3} \cdot 5 \mathrm{H}_{2} \mathrm{O}(5 \mathrm{mM})$. The assays were started by the addition of the sediment sample $\left(1 \mathrm{~cm}^{3}\right)$ to $15 \mathrm{ml}$ of medium. Sulphate reduction was inhibited by addition of $\mathrm{Na}_{2} \mathrm{MoO}_{4} \cdot 2 \mathrm{H}_{2} \mathrm{O}(20 \mathrm{mM})$. Samples were withdrawn after $4.5 \mathrm{~h}$ of incubation in the dark at room temperature and sterilized by filtration.

Measurements of sulphide formation: Sediment cores from the sampling site of Hiddensee were incubated either under anaerobic (plugged and kept dark) or aerobic (unplugged) conditions, and either illuminated or kept dark. Over a period of 12 hours the sulphide concentration was measured periodically at three depths in the supernatant water column. Sulphide production was approximated by integration. 


\section{RESULTS}

In order to evaluate the role of bacteria involved in the oxidation of reduced sulphur compounds in marine sediments, we analysed the top $20 \mathrm{~cm}$ of sediment from two different sampling sites along the coast of the Baltic Sea. Although the sediments from both areas showed active sulphate reduction and release of sulphide into the supernatant water, remarkable differences were found in the depth profiles of their chemical composition and in the distribution of bacterial activities. The sampling site at Hiddensee obviously was characterized by tremendous activity of sulphate-reducing bacteria and release of sulphide into the water; whereas sulphate reduction at the sampling site near Fährdorf appeared to be quite low. Nevertheless, sulphide was measurable in the thin water layer covering this sediment.

\section{The sediment at Hiddensee}

The chemical composition of this sediment is shown in Table 1. Minor salinity changes, between ca 9 and $12 \%$, occurred throughout the sediment. Most obviously, the sulphate content of the sediment was significantly reduced compared to the supernatant water. Particularly in depths between $3-8 \mathrm{~cm}$, the minimum values of the sulphate/ chloride ratio of 25.1 to 29.3 (calculated as indicated in Table 1) point to a zone of continuous sulphate depletion by sulphate reduction. This zone was accompanied by a maximum of the phosphate concentration. The nitrate pool was about 2-3 orders of magnitude lower than the sulphate pool, but showed significant changes throughout the sediment column, which indicates active turnover. According to the concentration gra-

Table 1. Chemical parameters of a sediment from Hiddensee. Values in brackets were taken from a dialysis pore water sampler. Parallel measurements by Völkel \& Schmidt (pers. comm.) revealed comparable concentrations of sulphide in the sediment. $\mathrm{OW}=$ surface water; $\mathrm{SN}=$ water close to the sediment surface

\begin{tabular}{|c|c|c|c|c|c|c|c|}
\hline & $\begin{array}{c}\text { Salinity* } \\
\%\end{array}$ & $\begin{array}{l}\text { Chloride } \\
\mathrm{mM}\end{array}$ & $\begin{array}{l}\text { Sulphate } \\
\text { mM }\end{array}$ & $\begin{array}{l}\text { Sulphate/ } \\
\text { Chloride"* }\end{array}$ & $\begin{array}{l}\text { Sulphide } \\
\qquad \mathrm{M}\end{array}$ & $\begin{array}{c}\text { Nitrate } \\
\mu \mathrm{M}\end{array}$ & $\begin{array}{c}\text { Phosphate } \\
\text { uM }\end{array}$ \\
\hline OW water & 9.88 & 154.3 & 7.75 & 50.2 & 8 & 3.4 & 3.1 \\
\hline SN water & 9.77 & 152.5 & 7.64 & 50.1 & 70 & 1.3 & 13.9 \\
\hline \multicolumn{8}{|l|}{ Sediment } \\
\hline $0-1 \mathrm{~cm}$ & 9.79 & 152.8 & 5.75 & 37.6 & (25) & 1.4 & 98.8 \\
\hline $1-2 \mathrm{~cm}$ & 11.07 & 172.8 & 5.45 & 31.5 & (25) & 3,4 & 124.7 \\
\hline $2-3 \mathrm{~cm}$ & 11.46 & 179.0 & 5.60 & 31.3 & $(47)$ & 20.1 & 87.7 \\
\hline $3-4 \mathrm{~cm}$ & 11.55 & 180.3 & 5.28 & 29.3 & (68) & 1.4 & 188.9 \\
\hline $4-6 \mathrm{~cm}$ & 10.85 & 169.4 & 4.52 & 26.7 & $(104)$ & 10.0 & 155.0 \\
\hline $6-8 \mathrm{~cm}$ & 10.32 & 161.2 & 4.04 & 25.1 & $(142)$ & 21.1 & 72.6 \\
\hline $8-10 \mathrm{~cm}$ & 10.41 & 162.6 & 4.93 & 30.3 & $(157)$ & 1.6 & 58.8 \\
\hline $10-15 \mathrm{~cm}$ & 9.91 & 154.8 & 5.05 & 32.6 & $(474)$ & 10.8 & 6.7 \\
\hline $15-20 \mathrm{~cm}$ & 10.32 & 161.1 & 6.35 & 39.4 & (1150) & 4.3 & 33.6 \\
\hline \multicolumn{8}{|c|}{$\begin{array}{l}\text { " calculated from the chloride concentration in \%o according to Wooster et al. (1969). } \\
\text { calculated from the concentrations (mM) and multiplied by 1000: (value of standard sea water } \\
\text { is } 51.7 \text { ). }\end{array}$} \\
\hline
\end{tabular}




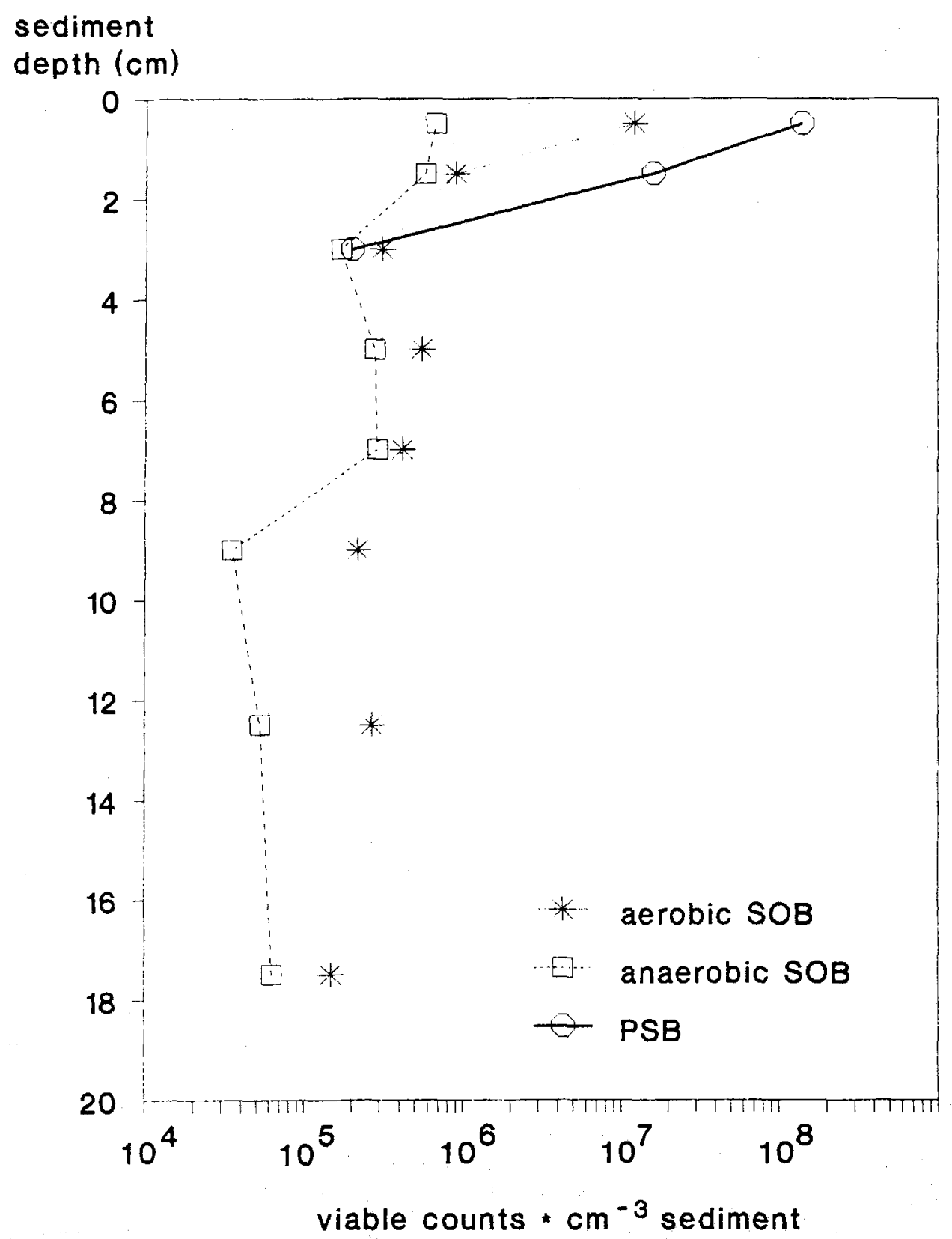

Fig. 1. Viable counts of sulphur-oxidizing bacteria at Hiddensee, $\mathrm{SOB}=$ Sulphur-oxidizing bacteria, PSB $=$ Purple sulphur bacteria; Viable counts of anaerobic SOB were determined under anoxic conditions with nitrate as electron acceptor 


\section{sediment \\ depth $(\mathrm{cm})$}

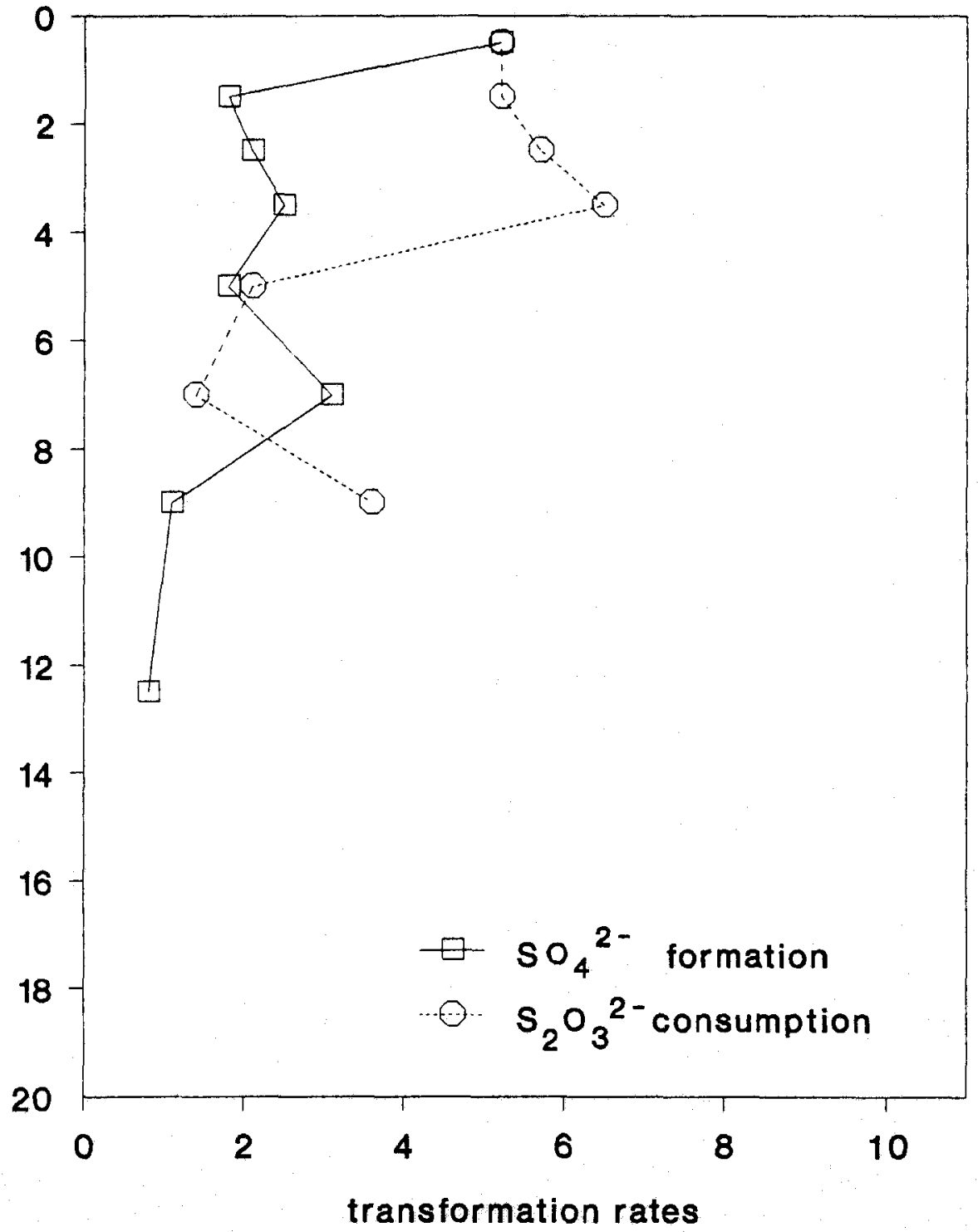

Fig. 2a. Transformation rates of thiosulphate and sulphate under aerobic conditions in the sediment from Hiddensee $\left(\mu \mathrm{mol} \mathrm{cm}^{-3}\right.$ sediment $\left.\mathrm{h}^{-1}\right)$ 


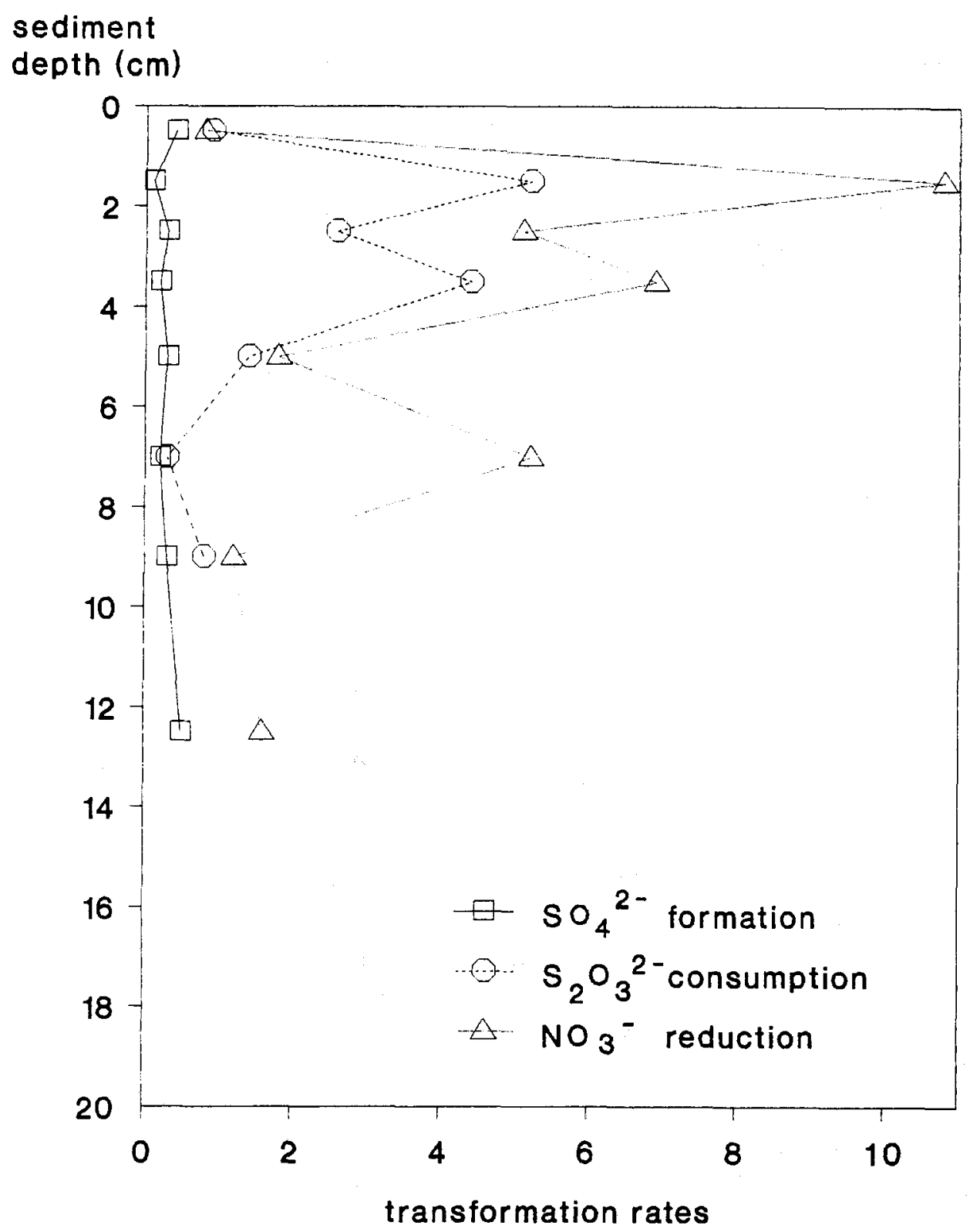

Fig. $2 \mathrm{~b}$. Transformation rates of thiosulphate, sulphate and nitrate under anaerobic conditions in the sediment from Hiddensee $\left(\mu \mathrm{mol} \mathrm{cm} \mathrm{cm}^{-3}\right.$ sediment $\mathrm{h}^{-1}$ ) 
dients during the sampling time, it can be concluded that the sediment is apparently a source of phosphate and probably a sink for nitrate. Sulphide was released from this sediment in significant amounts. Low concentrations of sulphide could be detected even in the oxic surface water of this site (Table 1, OW). Laboratory studies with natural sediment cores revealed that under conditions of blocked oxygen transfer and in the dark, the concentration of sulphide in the supernatant water increased considerably within $12 \mathrm{~h}$. The sulphide concentration amounted to $325 \mu \mathrm{M}$ directly at the sediment surface, $220 \mu \mathrm{M}$ at $3 \mathrm{~cm}$ above the sediment and $200 \mu \mathrm{M}$ at $6 \mathrm{~cm}$. Using these data, an exchange rate of sulphide between sediment and water of $14.4 \mathrm{mmol} \mathrm{m}^{-2}$ sediment $\mathrm{d}^{-1}$ was calculated. Thus oxygen availability is expected to be a limiting factor for sulphide oxidation in the top layers of this sediment, at least during dark periods.

Aerobic and anaerobic, nitrate-reducing sulphur-oxidizers as well as phototrophic sulphur bacteria had maxima of viable cell numbers in the top layer of this sediment (Fig. 1). Numbers of phototrophic purple sulphur bacteria exceeded those of all others, even those of aerobic sulphur-oxidizers. Because of their light-dependence, they formed a pink to red-coloured layer in the top millimetres of the sediment, just underneath a very thin surface layer. Viable counts decreased by one order of magnitude in the second $(1-2 \mathrm{~cm})$ and by two more orders in the third sediment disc $(2-4 \mathrm{~cm})$. Viable cells of phototrophic green sulphur bacteria were several orders of magnitude lower, ca $2-4 \cdot 10^{4}$ cells $\mathrm{cm}^{-3}$ in the top layers of the sediment.

Also cell numbers of chemotrophic sulphur-oxidizers using oxygen or nitrate as electron acceptors were highest in the top disc of the sediment. They dropped by about one order of magnitude below $2 \mathrm{~cm}$, but remained relatively high over the rest of the sediment down to 10-15 cm depth (Fig. 1).

The capability to oxidize thiosulphate under aerobic conditions was high in this sediment (Fig. 2a). Although sulphate was the major oxidation product, transformation rates of thiosulphate $\left(1.4-6.5 \mu \mathrm{mol} \mathrm{h}^{-1} \mathrm{~cm}^{-3}\right)$ were not quantitatively correlated with the formation of sulphate $\left(1.1-5.2 \mu \mathrm{mol} \mathrm{h}{ }^{-1} \mathrm{~cm}^{-3}\right)$. Obviously, thiosulphate is not exclusively oxidized to sulphate but to some extent transformed to other still unknown products.

Under anaerobic conditions in the presence of nitrate, thiosulphate turnover rates (0.3-5.2 $\mu \mathrm{mol} \mathrm{h} \mathrm{h}^{-1} \mathrm{~cm}^{-3}$ ) were in the same order as under aerobic conditions (Fig. $2 \mathrm{~b}$ ). However, lower amounts of sulphate $\left(0.1-0.5 \mu \mathrm{mol} \mathrm{h} \mathrm{h}^{-1} \mathrm{~cm}^{-3}\right)$ were formed. Thus, anaerobically, sulphate was a minor oxidation product. Sulphite was not an intermediate in thiosulphate transformations that accumulated during the incubation period. Other possible transformations of thiosulphate include oxidation to products other than sulphate, reduction or disproportionation. High nitrate-reducing activity (up to $10.8 \mu \mathrm{mol} \mathrm{h}{ }^{-1}$ $\mathrm{cm}^{-3}$ ) was present in this sediment and the maxima of nitrate reduction correlated with maxima of thiosulphate transformation (Fig. $2 \mathrm{~b}$ ). The highest values of both reactions were found in the first $1-2 \mathrm{~cm}$ of the sediment, a second maximum was at 3-4 cm depth. Both of these maxima correlated well with minimum values of nitrate in the sediment (Table 1).

\section{The sediment near Fährdorf}

Chemical composition and bacterial analyses revealed significant differences when compared with those of the sediment from Hiddensee. Though the salinity was only slightly higher (11-15\%), sulphate concentrations and in particular the sulphate/chloride 


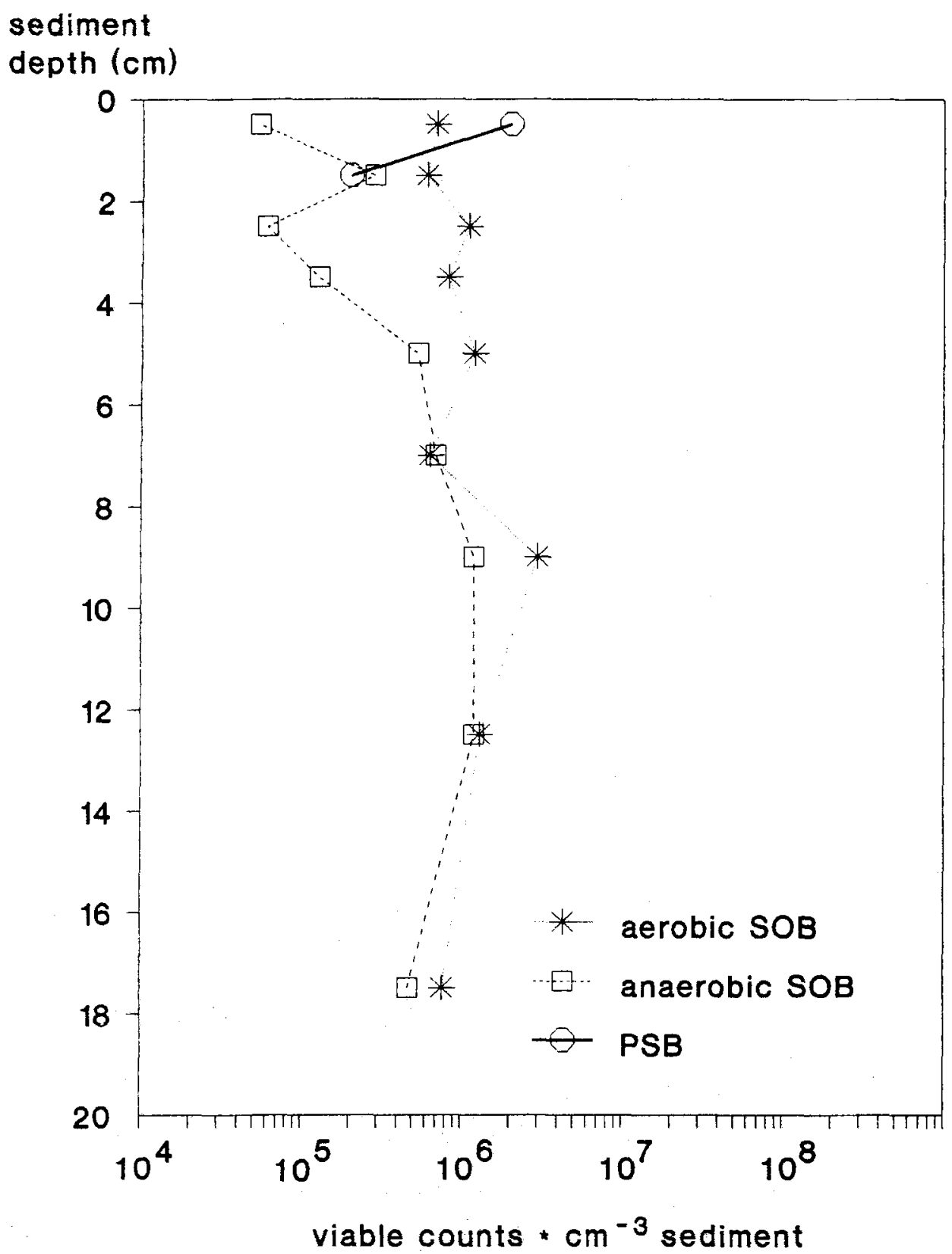

Fig. 3. Viable counts of sulphur-oxidizing bacteria at Fährdorf. SOB = Sulphur-oxidizing bacteria; PSB = Purple sulphur bacteria. Viable counts of anaerobic SOB were determined under anoxic conditions with nitrate as electron acceptor 


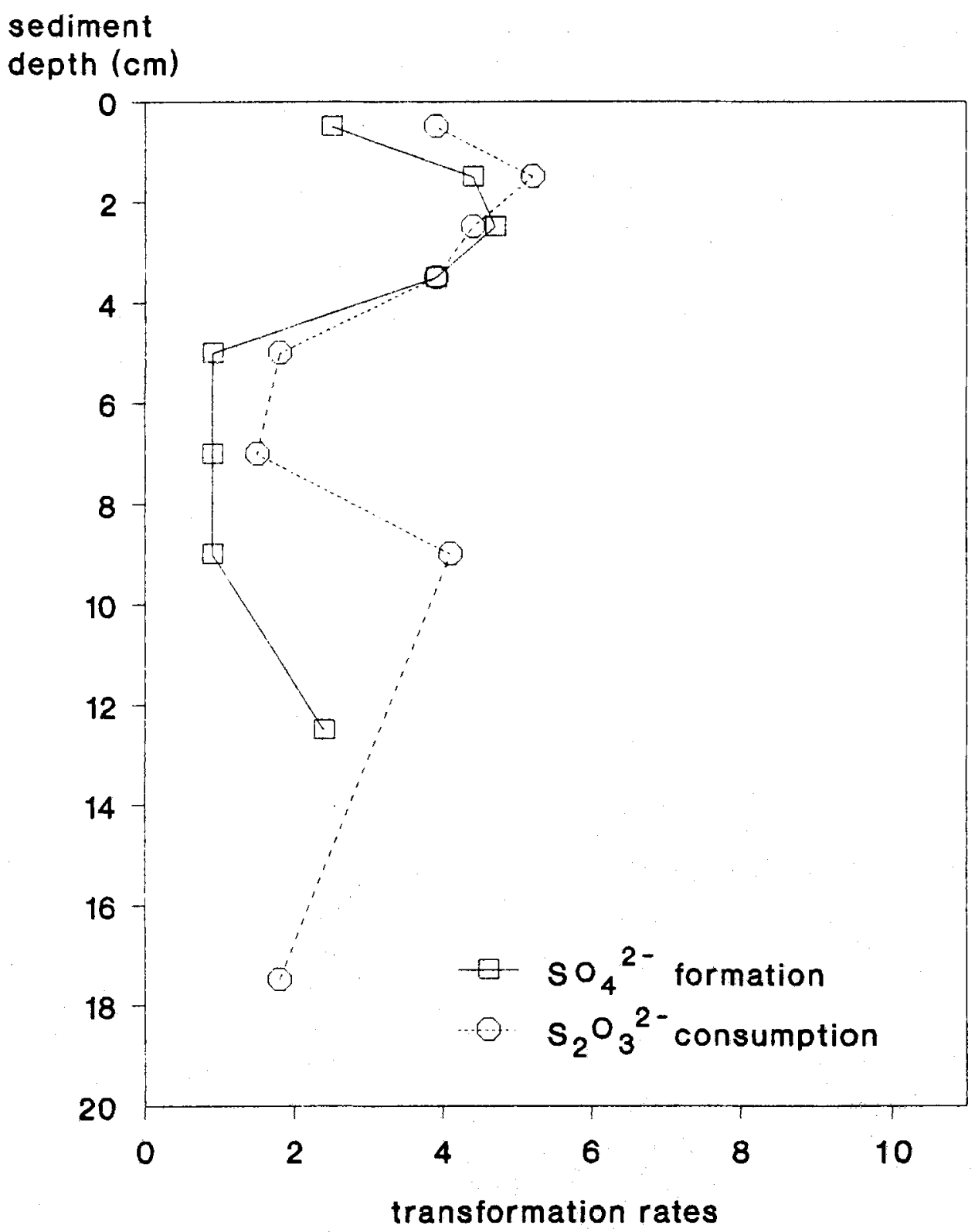

Fig. 4a. Transformation rates of thiosulphate and sulphate under aerobic conditions in the sediment from Fährdorf $\left(\mu \mathrm{mol} \mathrm{cm} \mathrm{cm}^{-3}\right.$ sediment $\left.\mathrm{h}^{-1}\right)$ 


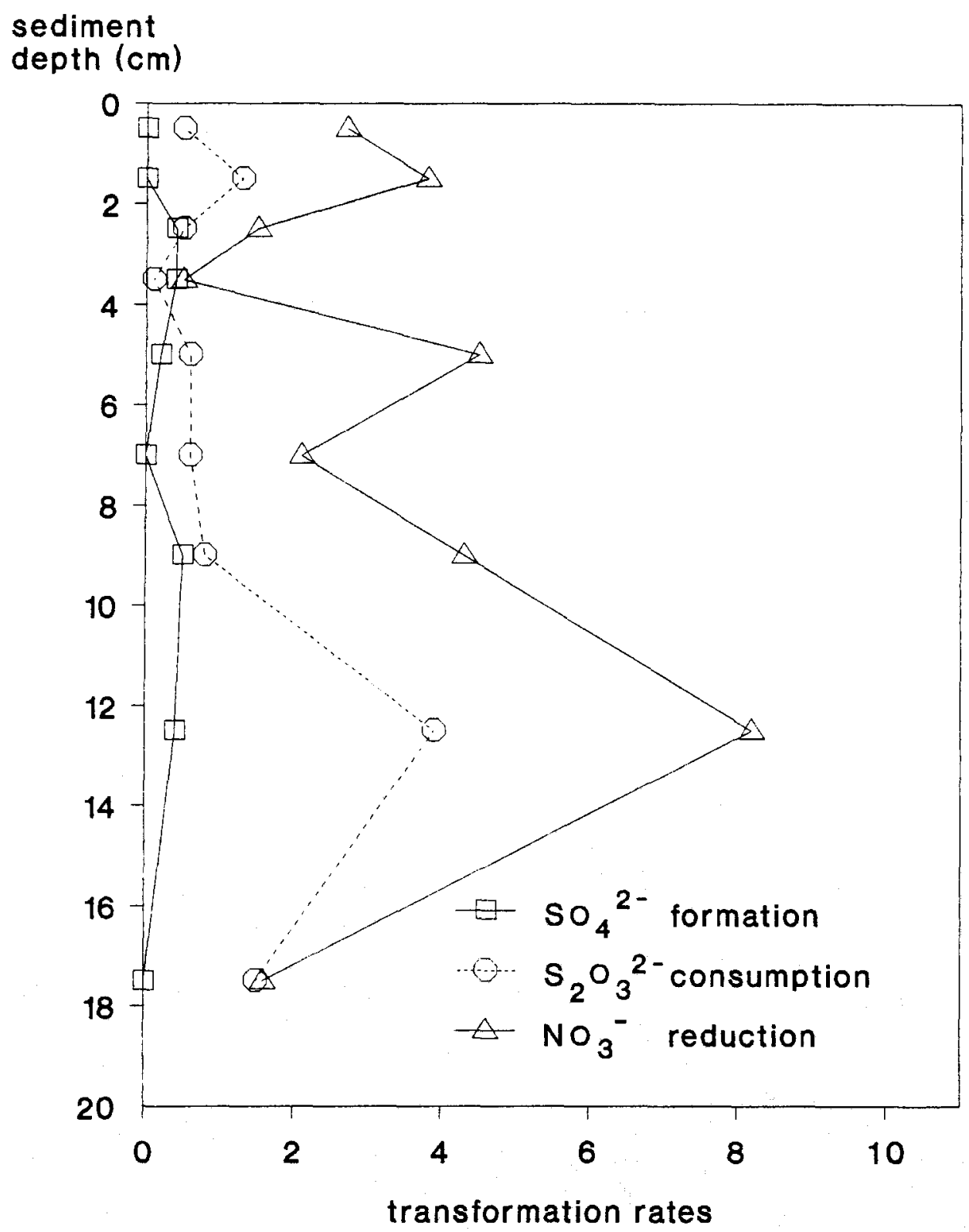

Fig. 4b. Transformation reates of thiosulphate, sulphate and nitrate under anaerobic conditions in the sediment from Fährdorf $\left(\mu \mathrm{mol} \mathrm{cm}^{-3}\right.$ sediment $\left.\mathrm{h}^{-1}\right)$ 
Table 2. Chemical parameters of a sediment from Fährdorf. SN = water close to the sediment surface; n.d. not detected

\begin{tabular}{|c|c|c|c|c|c|c|c|}
\hline & $\underset{\%}{\text { Salinity }}$ & $\begin{array}{l}\text { Chloride } \\
\text { mM }\end{array}$ & $\begin{array}{l}\text { Sulphate } \\
\text { mM }\end{array}$ & $\begin{array}{l}\text { Sulphate/ } \\
\text { Chloride* }\end{array}$ & $\begin{array}{l}\text { Sulphide } \\
\mu \mathrm{M}\end{array}$ & $\begin{array}{c}\text { Nitrate } \\
\text { uM }\end{array}$ & $\begin{array}{c}\text { Phosphate } \\
\text { ॥M }\end{array}$ \\
\hline SN water & 12.85 & 200.7 & 11.01 & 54.9 & 8 & 9.1 & 8.7 \\
\hline \multicolumn{8}{|l|}{ Sediment } \\
\hline $0-1 \mathrm{~cm}$ & 13.00 & 202.8 & 10.42 & 51.4 & 14 & 5.7 & 17.8 \\
\hline $1-2 \mathrm{~cm}$ & 13.30 & 207.7 & 11.10 & 53.4 & 12 & 45.6 & 0.1 \\
\hline $2-3 \mathrm{~cm}$ & 14.53 & 227.0 & 13.34 & 58.8 & 14 & 6.0 & n.d. \\
\hline $3-4 \mathrm{~cm}$ & 14.51 & 226.6 & 13.47 & 59.5 & 276 & 1.7 & 654.3 \\
\hline $4-6 \mathrm{~cm}$ & 15.17 & 236.8 & 13.36 & 56.4 & 139 & 34.6 & 169.8 \\
\hline $6-8 \mathrm{~cm}$ & 13.26 & 207.1 & 11.20 & 54.1 & 232 & 3.4 & 184.9 \\
\hline $8-10 \mathrm{~cm}$ & 13.92 & 217.3 & 10.65 & 49.0 & 29 & 3.4 & 394.1 \\
\hline $10-15 \mathrm{~cm}$ & 12.52 & 195.5 & 8.80 & 45.0 & 154 & 5.2 & 11.4 \\
\hline $15-20 \mathrm{~cm}$ & 10.49 & 170.8 & 8.21 & 48.1 & - & 27.0 & 6.1 \\
\hline \multicolumn{8}{|c|}{$\begin{array}{l}\text { " calculated from the concentration of chloride in "\% according to Wooster et al. (1969). } \\
\text { is } 51.7) \text {. }\end{array}$} \\
\hline
\end{tabular}

ratio were unusually high (Table 2), in particular at the 2-6 cm depth. Distinct layers with changing concentrations of sulphide (maximum at $3-8 \mathrm{~cm}$ ), nitrate (minima at $2-4 \mathrm{~cm}$ and $6-12 \mathrm{~cm}$, maxima at $1-2 \mathrm{~cm}$ and $4-6 \mathrm{~cm}$ ), and phosphate (strong minimum at $1-3 \mathrm{~cm}$, strong maximum at $3-10 \mathrm{~cm}$ ) were found. In particular, the enormous concentration gradient of phosphate, between very high values of more than $650 \mathrm{uM}$ at a $3-4 \mathrm{~cm}$ depth and undetectable traces at a $2-3 \mathrm{~cm}$ depth, points to highly active transformations. Similar to the sediment of Hiddensee, this sediment appeared to be a source of phosphate for the supernatant water.

Although lower numbers of aerobic and nitrate-reducing sulphur-oxidizers were present in the top layer of this sediment compared to those from Hiddensee (Fig. 3), viable cell numbers in the deeper sediment were in a similar order of magnitude in both sediments. Aerobic sulphur-oxidizers had quite constant cell numbers over the whole sediment core, with a slight maximum at a depth of $8-10 \mathrm{~cm}$. Nitrate reducers had a slight maximum at $1-2 \mathrm{~cm}$ and constantly high viable cell numbers from $4-6 \mathrm{~cm}$. An apparent mass development of phototrophic purple sulphur bacteria was not visible. Nevertheless, viable numbers of these bacteria were high in the top layer of the sediment $\left(2 \cdot 10^{6}\right.$ cells $\mathrm{cm}^{-3}$, see Fig. 3). Compared to an earlier sampling in April 1992, they had increased by three orders of magnitude, but still were two orders of magnitude lower than those from Hiddensee. Green sulphur bacteria were present in insignificant numbers and could not be quantified.

Activity measurements revealed maxuma of aerobic thiosulphate transformation at $1-3 \mathrm{~cm}\left(4.4-5.2 \mu \mathrm{mol} \mathrm{h}^{-1} \mathrm{~cm}^{-3}\right)$ and at about $10 \mathrm{~cm}$ depth $\left(4.1 \mu \mathrm{mol} \mathrm{h}^{-1} \mathrm{~cm}^{-3}\right)$ (Fig. 4a), sulphate being a major but not a stoichiometric oxidation product. Similar maxima appeared under anaerobic conditions with a thiosulphate turnover of $1.3 \mu \mathrm{mol} \mathrm{h} \mathrm{h}^{-1} \mathrm{~cm}^{-3}$ at $1-2 \mathrm{~cm}$ and $3.9 \mu \mathrm{mol} \mathrm{h} \mathrm{h}^{-1} \mathrm{~cm}^{-3}$ at $10-15 \mathrm{~cm}$ depth (Fig. $4 \mathrm{~b}$ ), but with minor proportions 
oxidized to sulphate. These rates coincided with maximum values of nitrate reduction in the same layers ( $3.8 \mu \mathrm{mol} \mathrm{h}{ }^{-1} \mathrm{~cm}^{-3}$ and $8.2 \mu \mathrm{mol} \mathrm{h} \mathrm{h}^{-1} \mathrm{~cm}^{-3}$, respectively) and high viable cell counts of nitrate reducing bacteria.

\section{DISCUSSION}

Quantitative enumeration of sulphur-oxidizing bacteria with selective media and measurements of potential transformation rates of thiosulphate and nitrate, combined with the chemical analyses of pore water indicated the importance of bacteria in the chemical processes occurring within the sediments. Furthermore, distinct maxima of several chemical parameters and of measured activities revealed a complex multilayered structure of the investigated sediments.

Although nitrate concentrations in the investigated sediments were quite low (below $10 \mu \mathrm{M}$, at maxima up to $50 \mu \mathrm{M}$ ), nitrate appeared to be an important electron donor for the oxidation of reduced sulphur compounds in sulphidic sediments. High numbers of nitrate-reducing bacteria and high potential activities of nitrate reduction and thiosulphate oxidation in the same sediment layers, i.e. $3-4 \mathrm{~cm}$ depth in the Hiddensee sediment and 1-2 cm depth in the Fährdorf sediment, point to an active role of these bacteria in the respective sediment layers. Although thiosulphate oxidation is stimulated in the presence of nitrate, sulphate is not formed in equivalent quantities. It appears, therefore, that sulphate is only a minor oxidation product of thiosulphate when nitrate is the electron acceptor. It is concluded that nitrate-reducing bacteria play an important role in the turnover of reduced sulphur compounds in anoxic parts of marine sediments, as long as nitrate is available.

The importance of aerobic sulphur-oxidizing bacteria in the top layer of the Hiddensee sediment is demonstrated by significant oxidation rates of thiosulphate to sulphate and by maxima of viable cell counts in this layer: In the dark and under conditions of blocked oxygen transfer between atmosphere and water column, the release of sulphide from the sediment surface into the water strongly increased, as shown by experiments with intact sediment cores. Therefore, oxygen is regarded as the most important electron acceptor for oxidation of reduced sulphur compounds in the surface layer of the sediments, and aerobic sulphur bacteria play a predominant role in these reactions.

High numbers and even maxima of (facultative) aerobic bacteria in the anoxic parts of the sediments point to their metabolic flexibility and their potential of anaerobic transformations. It is well established that denitrifying bacteria are facultative aerobes. Although a general conclusion on the participation of facultative aerobes in nitrate reduction in anoxic sediment layers is not possible, the occurrence of high numbers of aerobic sulphur bacteria in distinct sediment layers with maxima of denitrifying bacteria, active denitrification and minimum nitrate concentrations may be indicative of the metabolic activity of these bacteria under anaerobic conditions.

Phototrophic sulphur bacteria develop under anoxic conditions when light is available as an energy source and reduced sulphur compounds are present as electron donors. Because light penetrates only a few millimetres into the sediment, active growth of these bacteria is restricted to the small zone where light and reduced sulphur compounds coexist. They often form dense populations and appear as a coloured thin skin near the sediment surface, as found in the present study. These bacteria are of major importance 
for the oxidation of sulphide and other reduced sulphur compounds in the investigated sediments, as is demonstrated by their high numbers in the top sediment layers of both sampling sites. The active role of the purple sulphur bacteria in the oxidation of reduced sulphur compounds within the sediment is evident from the fact that most of their cells were filled up with stored elemental sulphur - an intermediate in the oxidation of sulphide to sulphate. Additionally, in sediment cores which strongly released sulphide into the supernatant water when oxygen supply was inhibited for 12 hours in the dark (13.5 $\mu \mathrm{M}$ sulphide), the major part of this sulphide was oxidized when oxygen was allowed to diffuse into water and when the sediment was illuminated. Only 1 to $1.5 \mu \mathrm{M}$ sulphide were released under these conditions during a $12 \mathrm{~h}$ period. Blackburn et al. (1975) demonstrated the predominant role of phototrophic bacteria by similiar experiments in sediment cores, too. Phototrophic sulphur bacteria and aerobic chemotrophic sulphur bacteria certainly are competing sulphur-oxidizers in the top layers of the investigated sediments, in particular because some of the phototrophic purple bacteria can use oxygen as an electron acceptor during chemotrophic growth (Kämpf \& Pfennig, 1980). We conclude that the combined action of both groups of bacteria most efficiently oxidizes reduced sulphur compounds in the top layers of the sediments. Nitrate may replace oxygen as final electron acceptor and will support oxidation of sulphide, in particular when oxygen and light are limiting.

Acknowledgements. This work was supported by the grant DYSMON A2 of the Bundesminister für Forschung und Technologie of Germany.

\section{LITERATURE CITED}

Blackburn, T. H., Kleiber, P. \& Fenchel, T., 1975. Photosynthetic sulphide oxidation in marine sediments. - Oikos 26, 103-108.

Feher, F. \& Laue, W., 1956. Beiträge zur Chemie des Schwefels. 29. Über die Darstellung von Rohsulfanen. - Z. anorg. allg. Chem. 288, 103-112.

Imhoff, J. F., 1988. Anoxygenic phototrophic bacteria. In: Methods in aquatic bacteriology. Ed. by B. Austin. Wiley, Chichester, 207-240.

Jörgensen, B. B., 1982. Mineralization of organic matter in the sea bed - the role of sulfate reduction. - Nature, Lond. 296, 643-645.

Jörgensen, B. B. \& Bak, F., 1991. Pathways and microbiology of thiosulfate transformations and sulfate reduction in a marine sediment. - Appl. environ. Microbiol. 57, 847-856.

Kämpf, C. \& Pfennig. N., 1980. Capacity of Chromatiaceae for chemotrophic growth. - Arch. Microbiol. 127, 125-135.

Lorant, I. S., 1929. Über eine neue colorimetrische Methode zur Bestimmung des Schwefels in Sulfiden, Sulfaten usw. - Hoppe-Seyler's Z. physiol. Chem. 185, 245-266.

Pachmayr, $F, 1960$. Vorkommen und Bestimmung von Schwefelverbindungen in Mineralwasser. Diss., Univ, München, $48 \mathrm{pp}$.

Pfennig, N \& Truper, H. G., 1992. The family Chromatiaceae. In: The Prokaryotes. Ed. by A Balows, H. G. Trüper, M. Dworkin, W. Harder \& K. H. Schleifer. Springer, New York, Vol. 4, 3200-3221.

Suckow, R, 1966. Schwefelmikrobengesellschaften der See- und Boddengewässer von Hiddensee. - Z allg, Mikrobiol, 6, 309-315.

Widdel, F., 1988. Microbiology and ecology of sulfate-and sulfur-reducing bacteria. In: Biology of anaerobic microorganisms. Ed by A. J. B. Zehnder. Wiley, New York, 469-585.

Wooster, W. S., Lee, A. J. \& Dietrich, G., 1969. Redefinition of salinity - Deep Sea Res. 16, 321-322. 